\title{
MONITORING AND GIS MAPPING OF GROUNDWATER LEVEL VARIATIONS IN GULBARGA CITY
}

\author{
Saleem A ${ }^{1}$, Dandigi M. $\mathbf{N}^{2}$ \\ ${ }^{1}$ Research Scholar PDA College of Engineering Gulbarga, current address: post box 897, Doha, Qatar \\ ${ }^{2}$ Professor, department of Civil Engineering, PDA College of Engineering Gulbarga, \\ abdussaleem@yahoo.com, mndandigi@yahoo.com
}

\begin{abstract}
Gulbarga is a fast developing city in Karnataka, India. Groundwater is a major source of water supply for the city which is reflected by regular extraction of groundwater through ever increasing number of municipal, industrial and private bore wells. Monitoring groundwater levels and quality is useful to understand impact of uncontrolled drilling of bore wells, point and non point sources of pollutants. Such studies provide early indicators of changes in groundwater resource and help to understand how to protect it. A total of 55 bore wells were selected for the study with one bore well per municipal ward of the city. Spatial coordinates were registered on site for each bore well with a GPS instrument and water depth below the ground level is measured during pre monsoon season using manual method. The results indicate wide fluctuations in groundwater depth across the municipal wards and the groundwater flow is found to follow surface relief in the study area. GIS map showing groundwater depth and level are developed and compared with surface relief map. These maps are very useful for urban planning and sustainable groundwater usage.
\end{abstract}

\section{Keywords: Groundwater, GIS mapping, Surface relief map, spatial distribution map}

\section{INTRODUCTION}

India is the largest groundwater user in the world. Groundwater has played a significant role in the maintenance of India's economy, environment and standard of living. Through the construction of millions of private bore wells, there has been an enormous growth in the exploitation of groundwater during the last five decades. It is reported that 56 per cent of metropolitan, class-I and class-II cities are dependent on groundwater either fully or partially [1]. As per census of India 2011, 27-35\% of urban population depends on groundwater as their source of drinking water[2]. About $29 \%$ of groundwater assessment blocks in the country are classified as semi-critical, critical or overexploited categories with the situation deteriorating rapidly. The government has no direct controls over the groundwater use of millions of private bore well owners both in rural and urban areas. A study by Hector et al 2011, report that the potential social and economic consequences of continued weak or nonexistent groundwater management are serious. Aquifer depletion is concentrated in many of the densely populated and economically productive areas, and the consequences will be more severe for the poor. Widespread groundwater pollution could render the resource useless before it is exhausted. It also must be noted that indiscriminate abstraction of groundwater aggravates the quality problems and thus a more integrated management approach to quality and quantity is needed [3]. Monitoring groundwater level fluctuation data on seasonal basis can identify early indicators of changes in the groundwater resource and help to understand how to protect it [4].Present study describes economic and rapid field method of groundwater level measurement from the existing bore wells fitted with hand pumps and electric motors. Spatial attributes of the sampling bore wells and development of GIS based maps showing groundwater depth and levels are also included.

\section{STUDY AREA}

Gulbarga is a historical and $6^{\text {th }}$ largest city of Karnataka state, spreads over an area of $65 \mathrm{sq}$. km with a population of about 541617 persons as per census of India, 2011. It is situated between longitude of $76^{\circ} 47^{\prime}$ east and $76^{\circ} 52^{\prime}$ east and latitudes of $17^{\circ} 17^{\prime}$ north and $17^{\circ} 22^{\prime}$ north. The city is divided in to 55 wards based on population and municipal jurisdiction. Average annual rainfall observed in the study area is about $750 \mathrm{~mm}$ and the mean daily temperatures range from $19^{\circ} \mathrm{C}$ in winter to over $40^{\circ} \mathrm{C}$ in summer. The City is served by piped potable water supply derived from Bennithora and Bhima rivers and Bhosga reservoir located $10-25 \mathrm{~km}$ away from the treatment plant. There are more than 1800 municipal bore wells in the city which augments city surface water supply and contribute to over $30 \%$ of daily municipal water supply to the city [5]. In addition to this groundwater is also extracted from thousands of private bore wells and consumed for potable purposes without proper treatment. There is no record of the number of private bore wells in the city. Based on a questionnaire survey it is noted that number of private bore wells in the city exceed 20,000 [6]. Groundwater level 
monitoring in the city is confined to only one observation bore well under the department of mines and geology, government of Karnataka. This observation bore well is located in an isolated area and does not reflect trends of groundwater fluctuations across the city. There are no previous studies reported in literature about groundwater levels monitoring in Gulbarga city. A site plan showing Gulbarga city and location of the bore wells selected for the study is shown in Fig. 1.

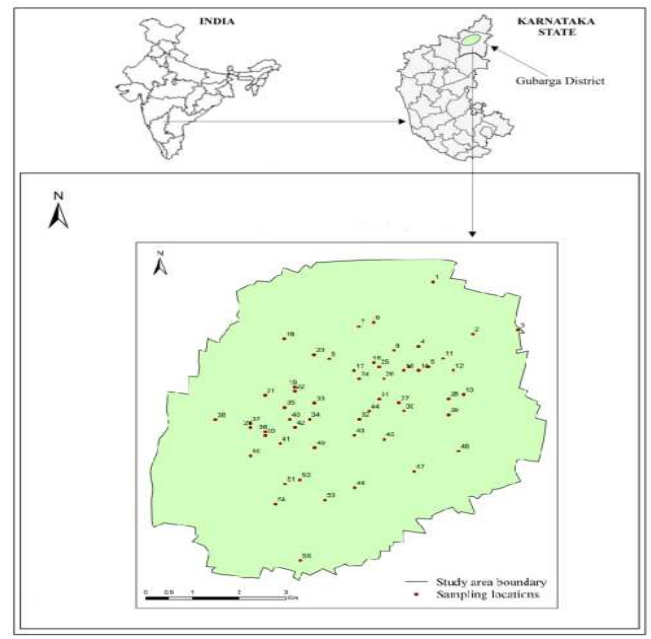

Fig.1 Study area and sampling bore well location

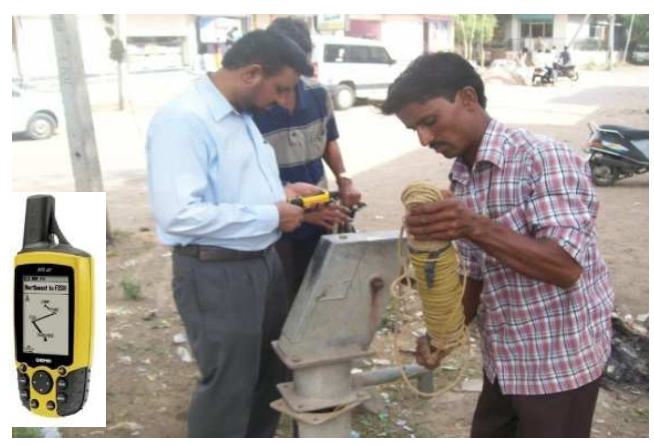

\section{MATERIALS AND METHODS}

Based on field observation 55 bore wells were selected for groundwater depth measurement. The selected bore wells are distributed throughout the city with one bore well located in each municipal ward. Spatial coordinates of the sampling bore wells were measured on site using a hand held global positioning system (GPS) instrument GARMIN GPS-60. Groundwater depth of the sampling bore wells were measured during pre monsoon season in the year 2009. Method consists of partially opening cover of the bore well/ hand pump and inserting a rope attached with a weight (spanner) at the lower end, through the casing of the bore well. This method is similar to the standard procedure described for measuring groundwater depth using a steel tape [4]. Fig. 2 shows the field measurement process. Depth to groundwater level was measured in $\mathrm{m}$ with the casing of the well as reference point and then deduced to exact ground level. Google earth is used to register ground level profile of the study area and ground level above mean sea level of the sampling bore wells. The groundwater level in MSL was obtained by deducting groundwater depth from the ground level in MSL.

Fig.2 Photos showing GPS instrument, and groundwater depth measurement

\subsection{Variation in Groundwater Levels}

Table 1 and 2 describe depth to ground water table in meter below ground level $(\mathrm{mbgl})$ and groundwater level expressed in $\mathrm{m}$ above MSL. Fig. 3 and Fig. 4 shows graphical trend of groundwater depth and level variations across the city.

\section{GIS DATA BASE AND GIS MAPPING}

In the present study, a spatial database has been created to store relevant GIS data for groundwater depth analyses with the coordinate system, universal transverse Mercator (UTM) zone $43 \mathrm{~N}$. The feature classes include, location point file generated using GPS, boundary line and polygon files generated from the ward map after geo-referencing with accurate GPS control point. Attributes like groundwater depth, groundwater level were then integrated to the location point file. These feature classes have been used for creating the following maps.

- Map of Gulbarga city

- Location of sampling bore wells

- Spatial distribution map(SDM) showing groundwater depth and level

- $\quad$ Surface relief map 
The study area map is generated from the hard copy of Gulbarga city corporation map (2006) gathered from district natural resources data management system (NRDMS) centre. The map was scanned, geo-referenced and digitised for creating the spatial database. Geo-referencing means to define its real location on earth surface in terms of map projections and coordinate systems. Here the process was carried out by integrating with the maximum number of GPS points taken from different parts of the study area.

Latitude, longitude and location of all the sample bore wells of study area were obtained using GARMIN GPS-60 receiver. ArcGIS software and location data using a point feature showing the position of sampling wells is prepared (Fig 1) using the attributes given in table 1 . Groundwater depth and level is stored in excel format as non spatial data and linked with the spatial data by join option in ArcMap. The spatial and the non-spatial database formed are integrated for the generation of SDM of groundwater depth (Fig 5) and levels (Fig 6). For generating the interpolation maps, inverse distance weighted (IDW) approach in GIS has been used to delineate the spatial distribution of groundwater pollutants.

Surface relief map (Fig 7) of the study area was generated from the elevation file representing the sampling locations plus additional points, falling within a grid of $1 \mathrm{~km}$ square, which in turn was extracted from the Google map. Using the 3D analyst extension tool in ArcGIS, location file was converted first to TIN (Triangular Irregular Network), which is the model representing a surface as a set of contiguous, nonoverlapping triangles. Within each triangle the surface is represented by a plane. These triangles are used for surface representation and display. Surface relief map is created by converting TIN raster file using the 3D analyst again. The map represents northern part with red colour indicating higher levels and the southern part with blue colour indicating relatively lower levels. This indirectly reveals the surface run off direction, which is from north to south. This map is prepared to understand surface runoff and comparing the ground surface profile with the SDM of groundwater level.

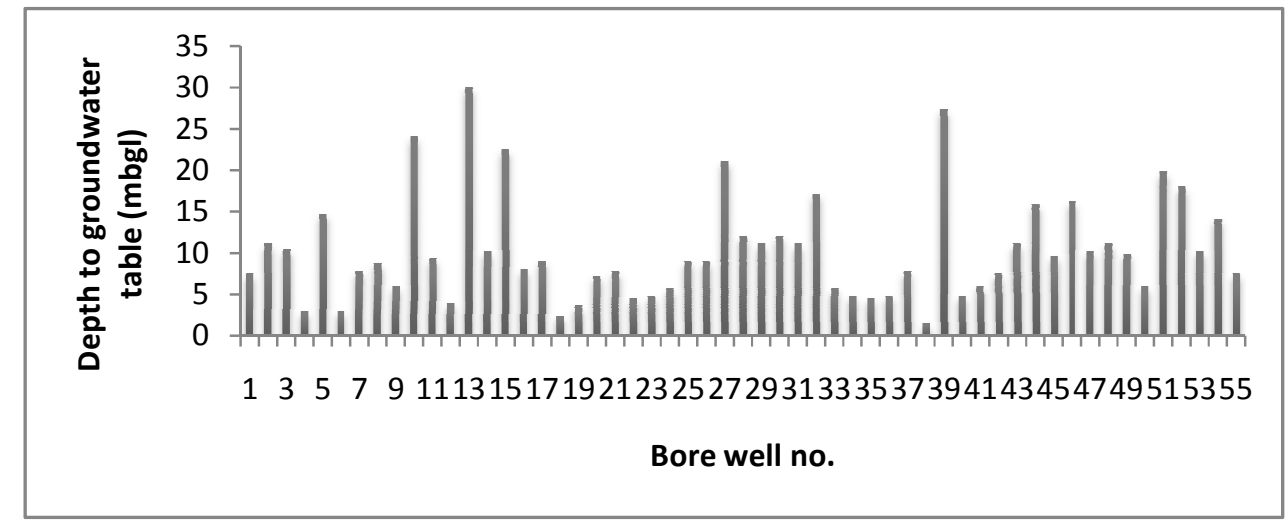

Fig.3 Variation in groundwater depth

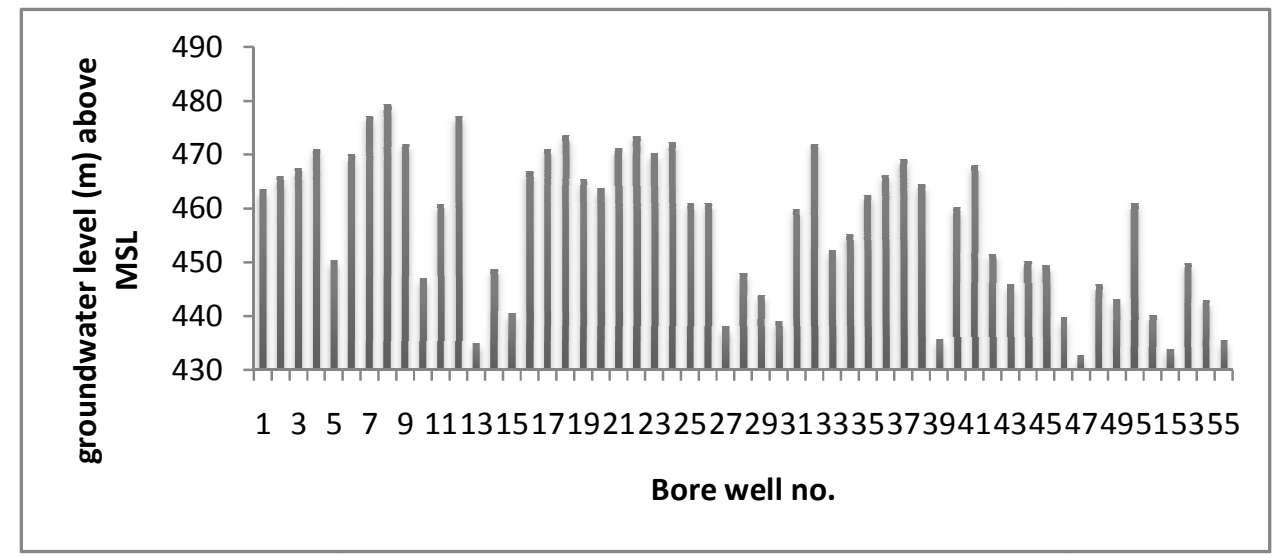

Fig.4 Variation in groundwater level 
Table 1 Attributes of sampling bore wells with Groundwater depth and levels

\begin{tabular}{|c|c|c|c|c|c|c|c|c|c|c|c|}
\hline $\begin{array}{c}\text { Bore } \\
\text { well No. }\end{array}$ & $\begin{array}{c}\text { Longitud } \\
\mathrm{e} \\
\text { (degrees) }\end{array}$ & $\begin{array}{l}\text { Latitude } \\
\text { (degrees) }\end{array}$ & $\begin{array}{l}\text { Ground } \\
\text { level* }\end{array}$ & $\begin{array}{c}\text { GW } \\
\text { depth } \\
(\mathrm{mbgl})\end{array}$ & $\begin{array}{c}\text { GW } \\
\text { level* }\end{array}$ & $\begin{array}{l}\text { Bore } \\
\text { well } \\
\text { No. }\end{array}$ & $\begin{array}{c}\text { Longitu } \\
\text { de } \\
\text { (degree } \\
\text { s) }\end{array}$ & $\begin{array}{l}\text { Latitude } \\
\text { (degree } \\
\text { s) }\end{array}$ & $\begin{array}{l}\text { Ground } \\
\text { Level* }\end{array}$ & $\begin{array}{c}\text { GW } \\
\text { depth } \\
(\mathrm{mbgl})\end{array}$ & $\begin{array}{c}\mathrm{GW} \\
\text { level* }\end{array}$ \\
\hline 1 & 76.853 & 17.368 & 471 & 7.5 & 463.5 & 29 & 76.856 & 17.335 & 455 & 11.1 & 443.9 \\
\hline 2 & 76.861 & 17.355 & 477 & 11.1 & 465.9 & 30 & 76.847 & 17.336 & 451 & 12 & 439 \\
\hline 3 & 76.871 & 17.355 & 478 & 10.5 & 467.5 & 31 & 76.842 & 17.339 & 471 & 11.1 & 459.9 \\
\hline 4 & 76.85 & 17.352 & 474 & 3 & 471 & 32 & 76.838 & 17.334 & 489 & 17.1 & 471.9 \\
\hline 5 & 76.852 & 17.347 & 465 & 14.7 & 450.3 & 33 & 76.829 & 17.338 & 458 & 5.7 & 452.3 \\
\hline 6 & 76.832 & 17.349 & 473 & 3 & 470 & 34 & 76.828 & 17.334 & 460 & 4.8 & 455.2 \\
\hline 7 & 76.838 & 17.357 & 485 & 7.8 & 477.2 & 35 & 76.823 & 17.337 & 467 & 4.5 & 462.5 \\
\hline 8 & 76.841 & 17.358 & 488 & 8.7 & 479.3 & 36 & 76.819 & 17.331 & 471 & 4.8 & 466.2 \\
\hline 9 & 76.845 & 17.351 & 478 & 6 & 472 & 37 & 76.816 & 17.333 & 477 & 7.8 & 469.2 \\
\hline 10 & 76.848 & 17.347 & 471 & 24 & 447 & 38 & 76.809 & 17.334 & 466 & 1.5 & 464.5 \\
\hline 11 & 76.855 & 17.349 & 470 & 9.3 & 460.7 & 39 & 76.819 & 17.33 & 463 & 27.3 & 435.7 \\
\hline 12 & 76.857 & 17.346 & 481 & 3.9 & 477.1 & 40 & 76.824 & 17.334 & 465 & 4.8 & 460.2 \\
\hline 13 & 76.859 & 17.34 & 465 & 30 & 435 & 41 & 76.822 & 17.328 & 474 & 6 & 468 \\
\hline 14 & 76.85 & 17.346 & 459 & 10.2 & 448.8 & 42 & 76.825 & 17.332 & 459 & 7.5 & 451.5 \\
\hline 15 & 76.847 & 17.346 & 463 & 22.5 & 440.5 & 43 & 76.837 & 17.33 & 457 & 11.1 & 445.9 \\
\hline 16 & 76.841 & 17.348 & 475 & 8.1 & 466.9 & 44 & 76.84 & 17.336 & 466 & 15.9 & 450.1 \\
\hline 17 & 76.837 & 17.346 & 480 & 9 & 471 & 45 & 76.843 & 17.329 & 459 & 9.6 & 449.4 \\
\hline 18 & 76.823 & 17.354 & 476 & 2.4 & 473.6 & 46 & 76.858 & 17.326 & 456 & 16.2 & 439.8 \\
\hline 19 & 76.825 & 17.342 & 469 & 3.6 & 465.4 & 47 & 76.849 & 17.321 & 443 & 10.2 & 432.8 \\
\hline 20 & 76.816 & 17.332 & 471 & 7.2 & 463.8 & 48 & 76.837 & 17.317 & 457 & 11.1 & 445.9 \\
\hline 21 & 76.819 & 17.34 & 479 & 7.8 & 471.2 & 49 & 76.829 & 17.327 & 453 & 9.9 & 443.1 \\
\hline 22 & 76.825 & 17.341 & 478 & 4.5 & 473.5 & 50 & 76.816 & 17.325 & 467 & 6 & 461 \\
\hline 23 & 76.829 & 17.35 & 475 & 4.8 & 470.2 & 51 & 76.823 & 17.318 & 460 & 19.8 & 440.2 \\
\hline 24 & 76.838 & 17.344 & 478 & 5.7 & 472.3 & 52 & 76.826 & 17.319 & 452 & 18 & 434 \\
\hline 25 & 76.842 & 17.347 & 470 & 9 & 461 & 53 & 76.831 & 17.314 & 460 & 10.2 & 449.8 \\
\hline 26 & 76.843 & 17.344 & 470 & 9 & 461 & 54 & 76.821 & 17.313 & 457 & 14.1 & 442.9 \\
\hline 27 & 76.846 & 17.338 & 459 & 21 & 438 & 55 & 76.826 & 17.299 & 443 & 7.5 & 435.5 \\
\hline 28 & 76.856 & 17.339 & 460 & 12 & 448 & & & & & & \\
\hline
\end{tabular}

*above mean sea level in m, mbgl- meter below ground level, GW - ground water

Table 2 Descriptive statistics for groundwater depth/level

\begin{tabular}{|c|c|c|c|c|c|}
\hline Groundwater depth/level & Range & Minimum & Maximum & Mean & Std. Deviation \\
\hline depth in m & 28.50 & 1.50 & 30.00 & 10.22 & \pm 6.26 \\
\hline Level in m above MSL & 51.80 & 427.50 & 479.30 & 459.42 & \pm 2.87 \\
\hline
\end{tabular}

\section{CONCLUSIONS}

Groundwater depth varies with bore well location from 1.5 meter below ground level $(\mathrm{mbgl})$ to $30 \mathrm{mbgl}$. Percent of bore wells showing water depth below $5 \mathrm{mbgl}$ is $21.8 \%$ whereas the percent below $10 \mathrm{mbgl}$ and $15 \mathrm{mbgl}$ are found as $58.2 \%$ and $81.8 \%$ in the same order. It is observed that both the groundwater levels and ground levels are receding towards south and follow almost identical pattern across the city. Variations in groundwater levels could be attributed to 
hydrogeology, land use and land cover changes across the city. Another important factor effecting groundwater level is the number of bore wells and rate of extraction of groundwater in the vicinity of the sample bore well. Shallow groundwater levels are observed at bore wells located close to wetland.
Regular monitoring of groundwater levels and groundwater quality shall be undertaken by authorities to control sustainable use of groundwater. It is recommended to increase the number of observation wells to cover each ward of the city.

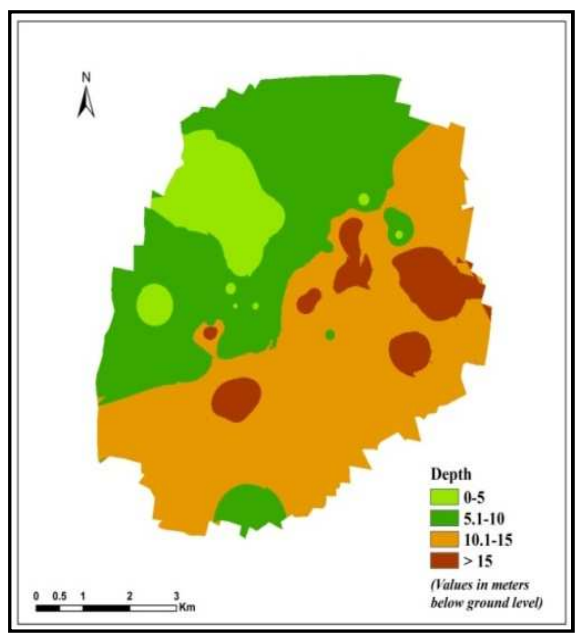

Fig 5 Depth of groundwater mbgl

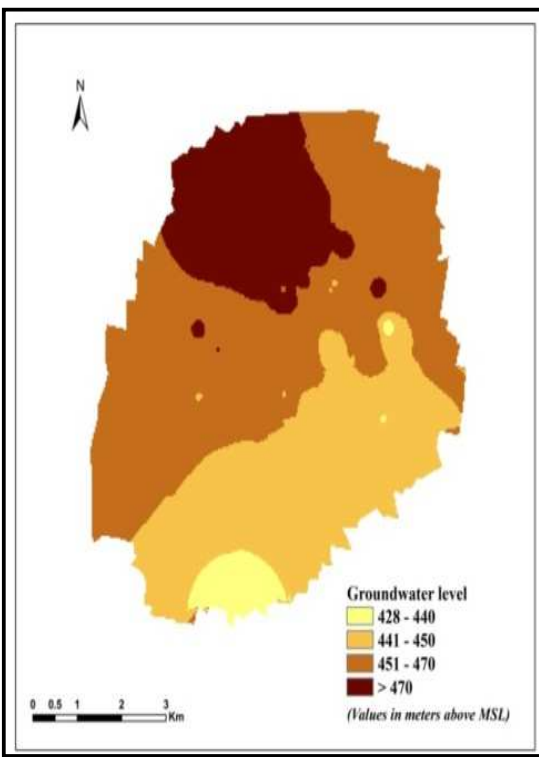

Fig 6 Groundwater level above MSL

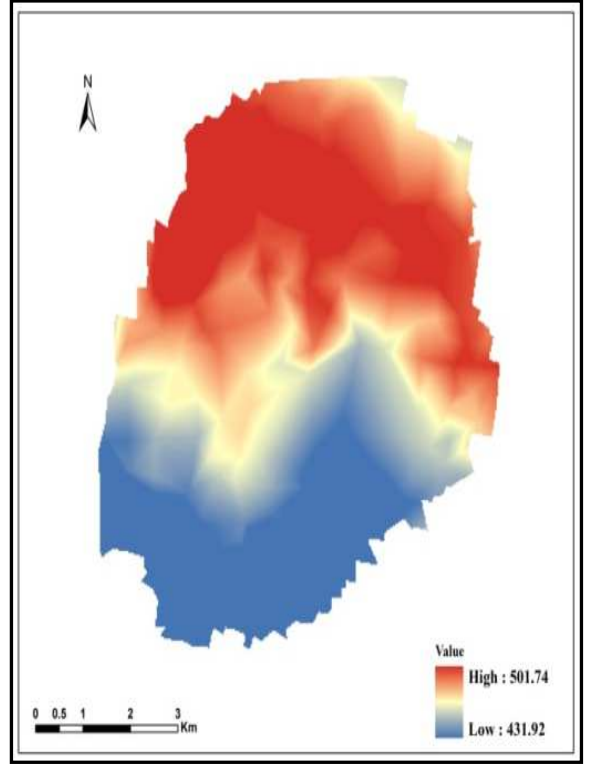

Fig 7 Surface relief map

\section{REFERENCES}

[1] NIUA (National Institute of Urban Affairs). Status of Water Supply, Sanitation and Solid Waste Management in Urban Areas, New Delhi, 2005.
[2] http://www.indiasanitationportal.org/1838, browsed 2601-2013

[3] Hector Garduno, Saleem Romani, Buba Sengupta, Albert Tuinhof and Richard Davis. "India groundwater governance case study". Water papers, the water unit, 
transport, water and ICT department, sustainable development vice presidency, the World Bank, 2011.

[4] R R Holmes Jr., P J Terrio, M A Harris and P C Mills. Introduction to Field Methods for Hydrologic and Environmental Studies. U.S. Geological Survey open file report 01-50, 2001.

[5] Gulbarga City Corporation. http://www.gulbargacity.gov.in, March 2010.

[6] A Saleem, M N Dandigi, K Vijay Kumar and P Balakrishna . "Groundwater Quality Assessment for an Indian Urban Habitat: A GIS Approach". Journal of Environmental Science and Engineering. 5: 1561-1569, 2011. 